\title{
Producing "internal suspect bodies": divisive effects of UK counter-terrorism measures on Muslim communities in Leeds and Bradford
}

DOI:

10.1111/1468-4446.12366

\section{Document Version}

Accepted author manuscript

Link to publication record in Manchester Research Explorer

Citation for published version (APA):

Abbas, M. (2018). Producing "internal suspect bodies": divisive effects of UK counter-terrorism measures on Muslim communities in Leeds and Bradford. British Journal of Sociology. https://doi.org/10.1111/1468-4446.12366

\section{Published in:}

British Journal of Sociology

\section{Citing this paper}

Please note that where the full-text provided on Manchester Research Explorer is the Author Accepted Manuscript or Proof version this may differ from the final Published version. If citing, it is advised that you check and use the publisher's definitive version.

\section{General rights}

Copyright and moral rights for the publications made accessible in the Research Explorer are retained by the authors and/or other copyright owners and it is a condition of accessing publications that users recognise and abide by the legal requirements associated with these rights.

\section{Takedown policy}

If you believe that this document breaches copyright please refer to the University of Manchester's Takedown Procedures [http://man.ac.uk/04Y6Bo] or contact uml.scholarlycommunications@manchester.ac.uk providing relevant details, so we can investigate your claim.

\section{OPEN ACCESS}




\section{BJS The British Journal of Sociology}

\section{Producing "internal suspect bodies": divisive effects of UK counter-terrorism measures on Muslim communities in Leeds and Bradford}

\begin{tabular}{|r|l|}
\hline Journal: & British Journal of Sociology \\
\hline Manuscript ID & BJOS-1647.R1 \\
\hline Wiley - Manuscript type: & Original Article \\
\hline Keywords: & counter-terrorism, extremism, Muslim, Prevent, suspect community \\
\hline Abstract: & $\begin{array}{l}\text { Research on UK government counter-terrorism measures has claimed that } \\
\text { Muslims are treated as a 'suspect community.' However, there is limited } \\
\text { research exploring divisive effects membership to a 'suspect community' } \\
\text { has on relations within Muslim communities. Drawing from interviews with } \\
\text { British Muslims living in Leeds or Bradford, I address this gap by } \\
\text { explicating how co-option of Muslim community members to counter } \\
\text { extremism fractures relations within Muslim communities. I reveal how } \\
\text { community members internalise fears of state targeting which precipitates } \\
\text { internal disciplinary measures. I contribute the category of 'internal } \\
\text { suspect body' which is materialised through two intersecting conditions } \\
\text { within preventative counter-terrorism: the suspected extremist for Muslims } \\
\text { to lookout for and suspected informer who might report fellow Muslims. I } \\
\text { argue that the suspect community operates through a network of relations } \\
\text { by which terrors of counter-terrorism are reproduced within Muslim } \\
\text { communities with divisive effects. }\end{array}$ \\
\hline
\end{tabular}




\title{
Producing "internal suspect bodies": divisive effects of UK counter-terrorism measures on Muslim communities in Leeds and Bradford
}

\begin{abstract}
Research on UK government counter-terrorism measures has claimed that Muslims are treated as a 'suspect community.' However, there is limited research exploring divisive effects membership to a 'suspect community' has on relations within Muslim communities. Drawing from interviews with British Muslims living in Leeds or Bradford, I address this gap by explicating how co-option of Muslim community members to counter extremism fractures relations within Muslim communities. I reveal how community members internalise fears of state targeting which precipitates internal disciplinary measures. I contribute the category of 'internal suspect body' which is materialised through two intersecting conditions within preventative counter-terrorism: the suspected extremist for Muslims to lookout for and suspected informer who might report fellow Muslims. I argue that the suspect community operates through a network of relations by which terrors of counterterrorism are reproduced within Muslim communities with divisive effects.
\end{abstract}

Keywords: counter-terrorism, extremism, Muslim, Prevent, suspect body, suspect community

Word count: 8,829

Date of submission: 10 December 2017 


\section{Introduction: co-opting Muslim communities in countering extremism}

Following the July 2005 attacks and recent terror attacks in London and Manchester, Muslim communities have been subjected to intensified monitoring and intervention from crime and security agencies which have constructed Muslims as a 'suspect community' in Britain (Breen-Smyth 2014; Hickman et al. 2012; Kundnani 2009; Mythen, Walklate and Khan 2009; Pantazis and Pemberton 2009, 2011). Previous studies on Muslim communities have examined detrimental effects of membership to a suspect community on relations with the police (Pantazis and Pemberton 2009: 660) and wider community, where targeting specific groups through counter-terrorism policing provides a 'permission to hate' the group under scrutiny (Poynting and Mason 2006). Less attention has been paid to divisive effects produced within the suspect community. Hillyard's (1993: 262) study exploring effects of state counter-terrorism on the Irish community which coined the term 'suspect community' remains the most comprehensive examination of the 'terror of prevention.' Key aspects include co-option of informers and stigma generated from within the suspected community where members are interrogated by counterterrorism agencies.

Hickman et al.'s (2012: 93) comparative research of representations of Irish and Muslim 'suspect communities' in Britain contends that 'suspectification' (the practice of making an individual or a community suspect) whilst initiated by state authorities, is reproduced by a range of individuals/groups, including within the community under suspicion. Internal divisions are engendered (Hickman et al. 2012: 99) from internal surveillance and responsibilisation of Muslim citizens to counter extremism within their communities (McGhee 2010; Mythen and Walklate, 2006; 
Thomas 2017). However, there remains a paucity of research exploring how divisions are created and experienced within the suspect community within the context of preventative counter-terrorism measures.

In addressing this oversight, I draw from qualitative interviews with 26 Muslim men and women living in Leeds or Bradford undertaken in 2010-2011. Bradford's prevalence in debates on Muslims' presence in Britain has predominated since the 1984 Honeyford Affair, 1989 Rushdie Affair, and 1995 and 2001 disturbances (Bagguley and Hussain 2008). Lewis (2002: 49, 24) describes Bradford as ‘Britain's "Islambad," arguing that South Asian Muslim communities dictate public perceptions about Islam and no other city has 'featured so centrally and consistently in shaping such attitudes.' Bradford is understood locally as less cosmopolitan than Leeds which masks heterogeneity of Muslim South Asian communities concerning cultural traditions, social classes, migration patterns, and denominations (Nasser 2003: 9). Muslims' presence in Leeds is not as pronounced, comprising three per cent (2011 Census) of the population compared to twelve per cent in Bradford. 82 per cent of the total Bradford Muslim population are Pakistani, compared to 65 per cent in Leeds meaning Muslims are predominately racialised as 'Asian looking' in these contexts.

Bradford's 'contested political history' (Sanghera and Thapar-Björkert 2008: 544) has shaped local responses to current counter-terrorism measures. Importantly, the 1995 and 2001 disturbances encouraged Bradfordian Pakistani Muslim women to find ways of '(re)defining intra- and inter-community relationships in the public sphere' (Burlet and Reid, 1998: 270). Leeds has a shorter history concerning Muslim visibility but also experienced a 'riot' in 2001, contributing to South Asian men's association with violence (Farrar 2009). Leeds gained prominence following the 2005 London bombings (Bagguley and Hussain 2012) and 
emergence of the 'home-grown terrorist category' as home-place to three of the four bombers. In 2008, Leeds became the new secret base of the West Yorkshire Counter Terrorism Unit comprising 400 counter-terrorism offices and staff.

The UK's counter-terrorism agenda has had a significant effect on civil society by enlisting communities to counter-terrorism (O'Toole et al. 2016; Spalek 2010). Prevent, the preventative strand of the UK government's counter-terrorism strategy, CONTEST, is premised on 'mobilising communities to oppose the ideology of violent extremism' (Kundnani 2009: 6). Initial funding for 'community-based approaches' to counter radicalisation came through the Preventing Violent Extremism Pathfinder Fund distributed by the Department for Communities and Local Government (DCLG) to 70 local authorities in England with a five per cent or more Muslim population, contributing to the suspect community thesis that simply being Muslim requires state attention.

During my research the Coalition Government issued a revised Prevent strategy identifying Leeds and Bradford as two of 25 'priority areas' for tackling terrorism (HM Government 2011: 97-8). Across 2009-2011 Leeds City Council and Bradford Council received $£ 686,341$ and $£ 1.02$ million respectively through Prevent (DCLG 2011). Since 2012, funding has been available from the Home Office for project work. Bradford received around £46,000 annually between 2012-15 and delivered seven projects. Bradford-based initiatives comprise the Future Leaders project that trained 500 young people on leadership skills, and work with the Bradford Council of Mosques to 'build the capacity of Imams, increase safety in buildings and engage in interfaith work' (Kundnani 2009: 19). These projects illustrate Prevent's attempts at capacity-building, encroachment on Muslim spaces 
and particular focus on ideological and youth counter-radicalisation initiatives (O'Toole et al. 2016: 162).

Recent policy has expanded the remit of the 'suspect community.' In particular, the Prevent duty introduced under the 2015 Counter-Terrorism and Security Act places statutory duty on local authorities, alongside a range of sectors, to have 'due regard to the need to prevent people from being drawn into terrorism' (HM Government 2015a: 10), and the 'Extremist Community Trigger' which places a legal duty on police and local authorities to respond to complaints concerning extremism. Amid concerns of young Muslims travelling to join IS, the number of Prevent priority areas increased to 46 in June 2015, including nearby Dewsbury, home to Talha Asmal, Britain's youngest suicide bomber. Priority areas now receive grants for a Prevent Coordinator to oversee a citywide approach to tackling extremism.

Prevent has attracted local criticisms centring on contradictions of community engagement being framed by anti-terror measures. Adoption of community cohesion policy following the 2001 disturbances framed communities, especially religious and ethnic minorities, as threats to social cohesion rather than sources of social integration (Cantle 2001). Husband and Alam's (2011) research in West Yorkshire found Muslim staff risked jeopardising community relations through association with Prevent which had generated hostility within Muslim communities. As Spalek and Imtoual (2007: 185) surmise, Muslims must negotiate 'a tenuous path between being a '“good" Muslim community member and/or being a "good" citizen.' Pressures arise within British Muslim communities through treatment 'as both problem and solution' (Spalek and McDonald 2009: 128). Local Prevent delivery continues to focus on communities to counter extremism. The Bradford District Prevent Action Plan (2015: 
4) approaches Prevent as a 'shared responsibility' with community engagement a ‘top’ priority. Similarly, Leeds City Council (2015: 3) emphasises the important role of faith institutions and communities, but argues 'there is still a great deal of work to be done to ensure that vulnerable individuals are safeguarded from being drawn into terrorism.'

Despite measures by Bradford City Council to increase transparency and accountability through a Prevent Community Reference Group and making the Prevent Action Plan publically available, Prevent remains 'divisive' according to Bradford Council Labour Leader, David Green. A leaked Home Office document (2015) of 'vetted' organisations receiving 1.2 million in Prevent funding (Cage 2017) posing as grassroots initiatives, including national campaign Inspire which has delivered workshops in Leeds, and Bradford-based initiatives, Choices: Alternatives to Extremism and Choices: Mainstreaming Prevent Education, have furthered distrust within Muslim communities.

This article contributes empirical analyses of internal divisions produced within Muslim communities within the context of government counter-terrorism measures through co-option of Muslims to spy and inform state authorities on Muslim community members (Cherney and Murphy 2016a; Spalek and Imtoual 2007: 185). It addresses two key limitations of existing work on suspect communities: firstly, its state-centric focus, and secondly, failure to adequately address internal differentiations within the suspect community. Connected to these domains is complicity of members of the suspect community in reproducing conditions of being suspect. I advance the category of 'internal suspect body' to address how terror is reproduced within Muslim communities from two intersecting situations: fear of suspected extremists and fear of suspected informers operating within Muslim 
communities. I approach 'community' as an unfixed category constructed interdependently by the state and individuals (Alexander 2007).

\section{Suspect community as networked and internally differentiated}

This section discusses my theoretical contribution of the suspect community as networked across state, group (intra-, inter-) and individual levels; further, as internally differentiated arising from heightened policing of suspected 'extremist' identities, including by other Muslims. In so doing, I shift the focus from 'state attention' which has plagued debates concerning the utility of the suspect community thesis (Pantazis and Pemberton 2009: 649). The main critic, Greer (2010: 1186), argues that while some Muslim individuals/organisations have attracted official suspicion, there is no empirical evidence of systematic or Islamophobic targeting of the majority of Muslims or that being Muslim is sufficient for arousing state surveillance. More usefully, Cherney and Murphy (2016a: 481) note that the term has been applied to capture 'the outcome of the cultural, political and ideological discourses that combine to define and consolidate Muslims as the "enemy within"” (Breen-Smyth 2014; Sentas 2014). Breen-Smyth (2014: 244) argues that effects of the suspect community are more pervasive than the minority under 'official suspicion.' For her, the suspect community does not just involve those targeted by counter-terrorism policing, but comprises a 'securitised imagination'; 'the suspect community is no longer conceptualised as an embodied community, but an imagined one, created in the imagination of a suspicious public.'

Whilst I support Breen-Smyth's departure from state-centric accounts, I do not suggest that the suspect community is no longer embodied; rather, the body is 
crucial to suspect treatment. Further, instead of focusing on non-members, I advance a networked approach that addresses how terrors of counter-terrorism are internalised by members of the suspect community and re-transmitted with divisive effects. This approach challenges distinctions between non/suspects suggested by Breen-Smyth (2014: 230) since those who suspect may also be members of the suspect community. Instead, I show how the suspect community is perpetuated through real and imagined terrors of state targeting that structure Muslims' relations with other Muslim community members and have psychic, emotional and ideological affects notwithstanding state targeting. My study builds on work such as Hickman et al. $(2012: 93,99)$ which engages with 'the full range of everyday encounters in which an individual might become aware of being "suspected,"' that are not confined to state policing, although this may be part of it, to address internal differentiations operating within the suspect community.

Utility of the term 'suspect community' has also received criticism from Greer (2008: 169) for not acknowledging differences within the Muslim community, arguing "it is extremely doubtful if there is a "Muslim community" in Britain in any meaningful sense.' Research has shown that Muslims' experiences, including of counterterrorism, differ depending on ethnic, religious and gender differences, suggesting greater discrimination is faced by 'visibly' Muslim individuals (Choudhury and Fenwick 2011: 8; Sheridan and Gillet 2005). Muslim women are increasingly securitised, reflected in current fears of British Muslim women joining IS to become 'jihadi brides' (Saeed 2016: 1). ${ }^{1} \quad$ Recognizing how certain groups are subjected to greater state surveillance, Pantazis and Pemberton (2009: 649) present a nuanced definition of suspect community: 
...a subgroup of the population... singled out for state attention as being 'problematic'. Specifically in terms of policing, individuals may be targeted, not necessarily as a result of suspected wrong doing, but simply because of the presumed membership to that sub-group. Race, ethnicity, religion, class, gender, language, accent, dress, political ideology or any combination of these factors may serve to delineate the sub-group.

This definition highlights how divisions may be created within the suspect community where members correspond more closely to 'problematic' Muslim identities. My advancement of the 'internal suspect body' addresses diverse ways suspectification operates depending on how the body is read by other Muslims. I locate my analysis within a framework of racial terror that emerged from participants' accounts that I have described elsewhere as the 'Concentrationary Gothic' (Author year). This framework addresses how terror affects multi-dimensions of subjects' experiences (relations, space, emotions, body, voice), across state, inter- and intra-group, and individual levels (i.e. terror is networked), and is shaped by racialized perceptual frameworks. This article focuses on the intra-group level (i.e. Muslim communities) and perceptual framework of subjection (Butler 1997). Analyses of concentrationary systems delineate how co-option of members of the subordinated group (Sofsky 1997: 13-44) and the 'pressure to conform' (Fings 2010: 113) are key terror tactics for ensuring subjection to the system. As Butler (1997: 2) contends, subjection 'signifies the process of becoming subordinated by power as well as the process of becoming a subject.' The moderate/extremist binary frames Muslims' judgments of other Muslims and precipitates internal mechanisms of control on religious activities, political views and relations with Muslim organisations through fears of association 
with extremism to avoid state targeting. In particular, I explore detrimental effects state co-option (actual and suspected) of Muslim individuals/groups under Prevent has on relations within Muslim communities (see Ragazzi 2016) by producing the internal suspect body as informer. I conclude that locally defined solutions that bridge policy and community voices, provide safe spaces for Muslims to articulate a range of identities and build relations locally are central to effective community engagement.

\section{Methodology}

The research is underpinned by what I term an 'inter-bodily-relational' (IBR) theoretical framework that approaches identities as constituted through a 'network of relations' (Foucault 1977: 26) with embodied, affective, vocal and spatial subjects situated within intersecting contexts (local, national, and international). The IBR develops from existing relational theories (Goldberg 2009; Hunter 2009) sensitive to how racialization shapes identity formations, making the (racialized/racializing) body central for understanding how relations between bodies are (re)constituted materially, discursively, and affectively.

A relational ontology supported sensitivities of researching a 'suspect community' (Sanghera and Thapar-Björkert 2008; Spalek 2011), including how I could be simultaneously positioned as challenging and reproducing the culture of fear affecting Muslims in Britain (see Hunter 2009: 185). The culture of fear operated in different ways in Leeds and Bradford because of their distinct histories. In Leeds, increased counter-terrorism presence post-7/7 meant organisations/individuals undertook internal surveillance to avoid state targeting. When making contact with a Leeds-based organisation, I was treated as 'suspect' 
and 'checked up on' despite being transparent about my research. Had it not been because one member was friends with a fellow PhD student, I might not have built trust as successfully. How my body was (mis)read contributed to my suspect treatment as someone who might be making contact in an undisclosed, official capacity. My Leeds-based gatekeeper told me people are 'probably suspicious of a "white girl" coming in and asking questions.' This experience highlighted how I contributed to the culture of fear affecting Muslims; further, that the body is an inadequate rubric for judging alliances. The body is nonetheless significant to suspectification. I decided to disclose my identity as half Iraqi and half English with Muslim heritage, which was important for gaining trust. I was an insider as someone of Muslim heritage and shared concern of the impact of the 'war on terror' on Muslims' experiences, but an outsider as a non-Muslim who could 'pass' as 'white English'. As I was not expected to know about Islam or being Muslim, participants provided detailed explanations of religious observance which enriched accounts.

Challenges undertaken in Bradford were related to its longer history as a site of research interest. In addition to the culture of fear, Bradford is 'research weary' (Sanghera and Thapar-Björkert, 2008: 544); a perspective shared by my key Bradford gate-keeper. Nonetheless, I was able to build contacts more easily in Bradford through a research placement. One contact/participant referred to me as 'legit' in an email sent to her networks which showed the importance of trust-building when researching within a culture of fear.

Counter-terrorism policy also posed research challenges. Under Prevent (2011: 3) universities are instructed to report to police 'potentially aberrant behaviour.' I was required by my University Ethics Committee to state on my participant consent form that confidentiality would be breached where 'criminal or 
other disclosures requiring action take place during the study.' My Leeds-based gate-keeper described the form as 'scary' because it criminalised Muslims as terror suspects. I removed the clause because it caused participants harm which contravenes ethical practice. The Prevent duty places increased pressure on higher education institutions to monitor academic research.

Data discussed in this article are from interviews conducted with 26 Muslim men and women aged 18-46 living in Leeds or Bradford in 2010-11. Respondents were recruited from any denominational, ethnic or national background to explore how individuals' experiences, including of counter-terrorism, may differ (Choudhury and Fenwick 2011: vi). Sampling combined purposive, snowball and opportunistic strategies. The Bradford-based sample developed from my research placement with a racial justice organisation which was networked to another key organisation focusing on Muslim women's issues. The Leeds-based sample built from participation with a local Stop the War group, Leeds University Islamic Society and other university contacts. I also attended various events/meetings relevant to local Muslim communities to get a sense of what was happening 'on the ground,' which informed interview questions. Half were from the Pakistani diaspora and a further six from other South Asian regions. The remaining six were Iraqi heritage (Leeds) or white British reverts in equal numbers. 24 were British and 17 British-born. An equal number of men and women were interviewed but the majority of women were Bradford-based.

Methods included developing a participatory social map which took participants' situated positions as the starting point of inquiry and oriented in-depth qualitative interviews lasting between one hour and a half and four hours. Maps explored different contexts comprising participants' social worlds (religion, family, 
work and so forth), relations formed within them, and their meaning to participants using three key words/phrases which provided important insight of intra- and intercommunity relations, including community work, and the role of religion. I chose not to use an interview schedule because I did not want to pre-empt the significance of the 'war on terror' context to participants' lives. Interviewing within a culture of fear posed ethical challenges. Participants reported threatening incidences which in keeping with a relational approach, required empathetic engagement.

Data analysis examined how participants are embedded in various intimate and wider social relations which impact identity constructions (Gilligan 1982). Analysis focused on the forms of governance involved in managing Muslim identities and how these traverse state, group (intra- and inter-), and individual levels of social experience. What emerged through analyses were different ways participants' experiences were shaped by a culture of fear.

\section{Policing Muslim identities within a culture of fear}

...putting the attacks to one side there are different types of fears on different types of levels - fears in terms of....what mosques can and can't do...fears in terms of Muslim women who are walking down the street...having to be vigilant, fears in terms of if you're a young Muslim man you can be stopped and searched...there's a heck of a lot of fears.

- Zanaib, ${ }^{2}$ 30-year-old Pakistani-heritage Muslim woman who wears hijab, Bradford 
Fear operates through both actual and imagined consequences of membership to a suspect community. The body is central to suspect treatment: religious, racialized, gendered and age-related categories intersect, producing heterogeneous experiences. Speaking as a 'visibly Muslim' woman, Zanaib describes differences in how Muslim women's bodies are insecuritised by heightened Islamophobia (Zempi and Chakraborti 2014), urging them to be 'vigilant,' and ways in which state practices of stop and search invade Muslim males' movements. Islamic spaces are in/securitised as well as Muslim bodies, illustrating how distinctions need to be drawn between 'suspect community' and 'suspect body.' Muslims are insecuritised regardless of involvement in terrorism ('putting the attacks to one side') in keeping with pre-emptive counter-terrorism frameworks (Mythen and Walklate 2009) and heightened Islamophobia (Breen-Smyth 2014). Fears of being targeted encourage internal disciplinary measures as Saba discusses:

....there's certain people within the Muslim community who are scared themselves and like in a gossiping way they'll be like...you can't do this or talk about this because they'll come and raid your house.... and it's true people's houses do get raided and they don't tell people because....it's embarrassing and it might leave a mark and people make assumptions and it is you know more common than it should be...but I think that amongst ourselves...we spend more time talking about that and scaring ourselves.

- 23-year-old Pakistani-heritage Muslim woman who wears jilbab and hijab, 
Saba describes how terrors of counter-terrorism affect Muslims' everyday practices ('you can't do this or talk about this'). Muslims become complicit in their own subjection and reproduce the culture of fear arising from being suspect by policing how members perform their Muslim identities. Restrictions comprise practices of 'regulatory power' (Butler 1997: 19) to mitigate dangers of state targeting by meeting requirements of 'acceptable Muslimness.' Saba speaks at other points of how, following her decision to wear the hijab and jilbab, she is subjected to internal controls by her family to display a 'moderate' Muslim identity (Author forthcoming). Fractures occur where community members resist conforming to recommended sanctions which might put other community members at risk. Important here is how state counter-terrorism practices invade intra-communal relations. Internal suspect bodies materialise where, even when innocent, those accused are 'brandished' within the Muslim community, highlighting important distinctions between 'suspect community' and 'suspect body' categories. Goffman's (1990: 11) description of 'stigma' as 'bodily signs designed to expose something unusual and bad about the moral status of the signifier' is useful for understanding how the accused, contaminated through the label 'terror suspect,' is treated as an internal suspect body. By making 'assumptions' about those subjected to state targeting, members reproduce suspect treatment so that it 'is more common than it should be,' as Saba decries. Psychic effects of subjection (Butler 1997: 19) are produced where shame of being (wrongfully) accused are internalised, precipitating self-surveillance to avoid suspectification by fellow Muslims. Not telling others of their ordeal illustrates how trust is compromised. The Association of Muslim Lawyers note that anti-terror raids can lead to "communities falling out within themselves due to the huge pressure that surrounds the community' in the aftermath (Nawaz and Warrich 2007: 7). 


\section{Suspect treatment and the body: intra-community differences}

The body is a significant site for negotiating suspect treatment. Hamida speaks of how some Muslims choose not to be 'outwardly Muslim' through fear of being stopped and searched; a practice which has had far reaching consequences on Bradford Muslim communities. According to Hamida, 'everybody knows somebody' who has been affected, meaning many 'just live in fear.' Only two participants did not mention the impact of the 'war on terror' context on Muslims' experiences. All participants discussed how contestations concerning dress affected intra-community relations and treatment by non-Muslims which played out differently in the research sites. These informed important distinctions between how the culture of fear operated in Leeds and Bradford relating to their different histories and patterns of migration. Bradford's density of Muslim communities was also discussed as offering safety. As Hamida explains:

In Bradford I feel very comfortable because I could be sat with a humungous backpack but nobody's going to feel that I'm going to do something wrong but even when we go to Leeds I sometimes feel a bit out of my comfort zone because it's still not as common in Leeds to wear hijab.

-24-year-old Pakistani-heritage Muslim woman who wears hijab and jilbab, Bradford

How the hijab is perceived is dependent, as Tarlo (2010: 51) writes, on 'sartorial norms prevalent in particular spaces.' These are significant for understanding internal differentiations operating within the 'suspect community.' Hamida highlights 
important geographical differences concerning suspect treatment relating to how the body is read, noting that in Leeds she would be treated with greater suspicion because the hijab is less common. Suspect treatment is differentially experienced depending on how the body is constituted through both state and individual relations which vary regionally, evidenced by Hamida's ability to avoid making others 'feel' she is threatening in Bradford even when displaying visual markers of a terror suspect ('a humungous backpack').

The events of $7 / 7$ have shaped the culture of fear affecting Muslim communities in Leeds following increased state targeting, particularly in Beeston where the attacks were allegedly planned. Samrina provides insight into how internal suspect bodies are produced in Leeds. Reporting on interviews by counterterrorism officers of Muslim male staff members following $7 / 7$, which her colleagues asked her to witness, she observes how the officers used clothing as indicators of extremism:

I heard them talking to some of the staff about the 'apparent bombers' and how they'd changed. One of the questions they were asking was around when did you notice his clothes change? When did he go from wearing Western clothes to wearing traditional clothes? And they aligned that with...extremism.

- 43-year-old Pakistani-heritage woman who wears hijab and jilbab, Leeds

Samrina highlights how state intrusion is differentially experienced depending on how the body is read or indeed reported, including by other Muslims, due to pressures placed on them to inform on those deciding to adopt 'traditional' clothes. Essentially, Muslims are co-opted into regulating expressions of Muslim identities. 
Samrina describes differentiations within the 'Muslim community' between those 'diluting their identity' to avoid state targeting by adopting Western clothes to blend into society, and 'visibly Muslim' men and women through Islamic markers and skin colour who she voices withdraw from society because 'they're getting treated so badly.' Through fear mobilised by counter-terrorism officials, Muslims become informers, complicit in producing internal suspect bodies to avoid becoming suspect themselves as Samrina continues:

I know how [counter-terrorism officers] had been operating in Beeston they'd been telling people lies about what they could do to them and people didn't know their rights, so people were then giving them information under fear of being arrested themselves - this is how deviously they behaved.

Muslim bodies are used by state officials to extend the scope of those under official suspicion with devastating effects on intra-community relations. Rafee similarly narrates how state counter-terrorism practices invade local Muslim communities. As with Saba, Rafee explains how the internal suspect body is produced through 'guilt by association' where individuals are interrogated by counter-terrorism officers. He discusses how a Leeds-based community centre run by a family friend is subjected to investigation by security services following claims that it was used as a meeting place for terrorist activities:

l'd been informed 'off the record' that the security services had questioned and bugged everybody in the building - people who I know very well and who are friends of mine so yeah it was a bit close to home.

- 32-year-old Kashmiri-English (non-practicing) male, Leeds 
Rafee shows how increased securitisation directly impacts his friends and, indiscriminately, community members attending the centre (by 'bugging' the building). Intra-community relations are detrimentally affected because pressures are not only placed on those subjected to official suspicion, but on the wider Muslim community through association with terrorism. He explains that these events also 'promoted' existing divisions between the local Muslim community and wider community. To counter suspect treatment, Rafee described how he and his friends organised a walk from Beeston to Leeds city centre to bring Muslim and non-Muslim communities together. This event was important for Muslims to be seen locally as neighbours/friends rather than suspects who are also adversely effected by terrorism. Co-option of Muslim community members to counter extremism under Prevent fuels Muslims' treatment as suspect however, as the next section explores.

\section{Prevent: co-opting Muslim community members}

Prevent funding has prompted polarised responses in Bradford as Zanaib reports: rejection due to its 'connotations' with extremism or opportunities to 'build structures.' Following the decline of the woollen-textiles industry since the 1970s, Bradford is the second most deprived city in the West Yorkshire and Humber district (IMD 2015). Four key criticisms of Prevent were raised: 1) poor funding allocation; 2) ineffective engagement with Muslim organisations; 3) pressures imposed on Muslim communities to come up with solutions assuming they know where terrorists are and how to deal with them; and 4) branding 'the Muslim community' homogeneously as suspect (Mythen 2012: 414-416); a situation which not only challenges state-centric accounts offered by Greer (2010: 1186), but creates conditions in which internal suspect bodies thrive. In exchange for Prevent funding, Muslim organisations are 
coerced into informing on attendees at local community events which exploits socioeconomic inequalities in Bradford that have disproportionately affected Pakistani Muslim communities (Husband and Alam 2011: 6) and importantly, co-opts Muslims into producing suspect bodies internally as Zanaib describes:

...the police have said in terms of the Prevent stuff that we'll give you funding but we want the names and contact numbers of all the people that attend.

Placing all attendees under the panopticon gaze of counter-terrorism (Mythen 2012: 414) detrimentally impacts intra-community relations because Muslims disengage from organisations through fear of being monitored as Saba narrates:

Saba: $\quad$ On the community level I was seeing the divides being created so and so's taken Prevent money, don't talk to them... that was quite frustrating, especially when l'd seen some really good projects that were breaking down because of it.

Interviewer: Right.

Saba: $\quad$...and just the mistrust that was created within the community like if you're on Prevent then everyone's who's part of that project is going to be spied on and you can't work with them....that was quite a problem...

Rather than facilitating effective partnerships, 'mistrust' is generated internally through suspected complicity in state agendas. Organisations impose internal 
controls ('don't talk to them') on working with those in receipt of Prevent funding (Spalek and Imtoual 2007: 185, 193), meaning effective community projects collapse. The internal suspect body is a relational category produced through intersecting conditions: the suspect extremist who is 'spied on' and the Muslim informer, illustrating how suspectification is networked across state and Muslim relations and engenders internal divisions.

Pressures placed on Muslims, particularly males, to work for intelligence agencies evidences the coercive (and gendered) nature in which state authorities coopt Muslims to spy as Zanaib explains:

Recently I had phone calls....from young men who said that they'd been followed by MI5 who wanted them to work for them...someone rang me and said.... we're aware of a young man who is constantly being hounded by...MI5 and we know they're MI5 because that's what they say.... and they want him to spy, and he said look this guy is more than willing to do whatever they ask but it has to be legitimate, it has to be a contract - if they want him to work for MI5 do it...the way you would...with anybody else....do it properly - but they're refusing to.

Zanaib describes how Muslim bodies are used instrumentally by intelligence agencies to inform on fellow Muslims. Failure to make contracts transparent illustrates how Muslims are used as political prawns rather than equal partners, placing Muslims in a compromised position within their communities because they are unable to verify the legitimacy of the operation. A recent government report (HM Government 2017: 33) states that covert investigatory techniques are 'critical' to 
countering terror threats, with M15 one of nine agencies able to obtain an interception warrant. Saba reports how a government advisory group placed similar coercive demands on her to inform. Here again, Muslims are not engaged with on equal terms or able to feed into policies affecting their communities.

Saba was a grassroots organiser in Bradford when interviewed. She was also a member of a government advisory group involving Muslim young people aged 1726 launched in 2008 funded by the Department for Communities and Local Government and Department for Children, Schools and Families. Its expressed function was to 'work directly with the government to help deepen its engagement with young Muslims' (Communities and Local Government n.d.) as part of Prevent's shift in government relations with Muslim religious, civil and community organisations to engage directly with Muslim youth (O'Toole et al. 2016: 162). Saba tells me she joined because she thought it was 'fantastic' young Muslims were given a 'voice.' As Rashid (2013: 592) argues in her study of the state's attempt to 'give voice' to Muslim women through the National Muslim Women Advisory Group, initiatives to empower Muslims under Prevent are only comprehensible within a 'wider policy trajectory in which an imagined, essentialized Muslim community is pathologized.' Membership risks not only reproducing pathologized representations of Muslim communities, but constrains Muslims' voices by co-opting them in pre-set agendas as Saba describes:

They just....used to have us at a conference sat there and just you know ticking certain boxes to make sure that yeah here's young Muslims and they're advocating what we're doing when we clearly weren't. 
Amiraux (2016: 44) writes that in liberal democracies visibility is connected to 'citizen participation and recognition,' and equated with being allowed a voice. Conversely, Saba shows that young Muslims' presence is tokenistic. Rather than providing space to contribute to Prevent, they are made inadvertent accomplices in its detrimental impact. Young Muslims' presence presents a semblance of conformity and justification of government agendas which negatively affects their position within their communities because they are judged by the policies that are put forward despite disagreeing with them. Saba discusses her objection to the intrusive, disciplinary nature of Prevent that she is not only unable to challenge, but is actively coerced by state actors to enforce:

Interviewer: What was it about the treatment of young people that you particularly...?

Saba: I think the primary thing is just...the surveillance aspect....and thinking they can intrude into young person's lives...they quite obviously said to us we want you to be key members within the community, you can inform us of what's going on and people were like how in-depth is this inform-information? They're like you're interacting with young people you could easily make reports....this is a little bit too much....

Saba reports how group members became increasingly wary of expectations put on them to act as informers on their communities (Kundnani 2009: 6). Through being made into 'key members,' these chosen young Muslims are well-placed by the government to undertake the 'detailed work of terror' by surveilling and reporting on their communities (Sofsky 1997: 130). Co-opting young Muslims to act as informers 
produces internal suspect bodies by reaffirming conceptions of extremism as endemic to Muslim communities as well as blurring the boundary between friend and accomplice; a tactic of terror that Sofsky (1997: 130) describes as characterising camp spaces. As Sofsky explains, introducing a 'graduated power of delegation' through internal surveillance prevents solidarity.

Lack of transparency concerning information gathering highlights the coercive nature in which information under Prevent is compiled and explains the group's unease: 'how in-depth is this inform-information?' A report by An-Nisa Society identifies how information is obtained 'from unsuspecting Muslims under false pretences' (Khan 2009: 20) and used by police and security agencies to identify 'security risks,' causing fear within Muslim communities. The Revised Prevent Duty Guidance (HM Government 2015a: 4) states that Prevent, 'must not involve any covert activity against people or communities.' However, authorities are allowed to share personal information where individuals are 'identified as at risk of radicalisation.'

Whilst Saba joined the advisory group under the premise that she would have a voice to shape policies affecting young Muslims that would benefit them, she realises the unsavouriness participation entails which unsettles her: 'this is a little bit too much.' Prevent's disciplinary effects undermine grassroots workers' relationships with young Muslims and importantly, hinders their ability to counter extremism by closing down 'safe spaces' for Muslims to engage:

Saba: as a grassroots worker I think young people are entitled to have that privacy and that safe space to express themselves 
Interviewer: Sure.

Saba: $\quad$ And they became very scared to do that.

Interviewer: Right. So did they actually say to you that they wanted you to inform?

Saba: $\quad$ Yeah

Interviewer: On the community?

[Saba nods]

Using young Muslims to undertake covert surveillance of other young Muslims shows how state practices invade young Muslims' lives, violating 'safe spaces' for young Muslims to interact through fear that their words will be misreported as evidence of extremism. By self-silencing, young Muslims become agents in their own subjection (Foucault 1977: 203), illustrating the ideological and reproductive effects of terrors of counter-terrorism experienced within Muslim communities. A core part of Prevent's counter-ideological work is the Channel programme which relies on a number of actors, including youth workers, to report individuals 'at risk of extremism' 
to police. The programme is now a legal requirement under the 2015 CounterTerrorism and Security Act and each local authority must have a Channel panel to decide on referrals (HM Government 2015b).

Occupying a 'moderate' Muslim subject position is part of how subjection works; it functions as a 'qualified Muslimness; a muted alterity' (Tyrer 2008: 59). This category was treated with hostility by several participants (see Cherney and Murphy 2016b). Muslims are nonetheless co-opted into maintaining the moderate/extremist binary that not only reproduces the conditions under which they are made suspect, but restricts how Muslims perform their identities and communicate with other Muslims as Saba discusses:

...this whole like moderate extremist thing - it's dividing the Muslim community ...what Prevent said is that it's the Muslim community's problem and we had to provide the solution...But it still had to be their solution and it was a certain version of Islam....and it was just too...prescriptive.

Saba argues that Prevent's approach to community engagement is fundamentally flawed because it is premised on a restrictive and divisive conception of 'acceptable' Islamic interpretation which risks alienating Muslims from the state and each other. Internal divisions are engendered because communities are pressurised into countering extremism according to state requirements ('it still had to be their solution') rather than locally defined solutions which can empower members.

\section{Empowering communities: locally defined solutions}


In this final section, I focus on the Muslim Women's Council (formerly Bradford Muslim Women's Council) as an example of a successful community initiative to highlight the importance of locally defined solutions for empowering communities. The emergence of the organisation was not without contestation, reflecting local intra-community tensions concerning Islamic practice and the role of women and external political pressures. Zanaib describes the 'silent revolution' undertaken by Bradfordian Muslim women following the 2001 disturbances to support local Muslim communities and develop Muslim women's visibility in public debates where traditionally men had acted as community representatives. Moors and Tarlo (2007: 136) note how dress plays an important role as 'a visual intervention and medium of debate in the public sphere.' As an accomplished veiled Muslim woman, Zanaib tells me she was 'thrust' into the public arena because she was 'marketable' as a 'role model' to 'represent the community' whom she felt claimed 'ownership' of her, but which also afforded her a 'privileged' position. Established in 2009 to 'represent Muslim women,' the MWC developed from conversations with over 100 Bradfordian women as part of a Joseph Rowntree funded project. It aims to 'bridge' policy and 'community voices':

you've got... a structure...that is locally defined, that has women involved, that is able to say ok we know about all these issues but this is what we're saying we want ... in terms of power dynamics we're coming to the table because we have something to offer...

Unlike government funded organisations, the National Women's Advisory Group and recently exposed, Inspire, that posed as a grassroots initiative, Zanaib argues that 
organisations must be 'locally defined' so women are empowered to define outcomes ('this is what we want'). She describes how the MWC builds positive community relations:

...we're going to be nurturing that confidence, [Muslim women are] going to be able to.....act as that bridge and have...impact.

By 'nurturing' young Muslim women, including several of my participants, the organisation provides a counter to state co-option. Rather than enlisting Muslims as informers, they are empowered to bridge policy and community voices and shape outcomes in ways that will benefit local communities based on local knowledge and need. Building trust and confidence within Muslim communities is required to resist state intrusion:

...in terms of the policy side of things they have been saying... we want to use you, we want to tap into you and we've just had to.... reign ourselves in.

To retain integrity amongst local Muslim communities, organisations must withstand the exploitative pull of policy makers. An important component is devising Muslimled spaces for intra- and inter-community dialogues, such as the MWC's City Circle:

The City Circle is something that is led by us...it's literally you have speakers...open to all people but the issues that we focus on have been brought up by women...it's a safe, open space...that is Muslim-led.. but there are also spaces that are closed because internal conversations need to take place because it's something that's based on a premise, it's about Muslim 
women, it's about the political context, it's about women saying there has to be a bridge between community voices and policy makers.

Where Saba reported self-silencing undertaken by young Muslims, here Muslim women are actively engaged in opening up safe spaces through Muslim-led conversations to build relations internally ('internal conversations need to take place') as well as supporting relations inter-communally and with the state by acting as a 'bridge.' The initiative facilitates a networked response to the culture of fear affecting Muslim communities that addresses internal differentiations within Muslim communities by supporting diverse expressions of Muslim identities and impact of state policy on Muslims' lives/communities.

\section{Conclusion: preventing terror}

This article has shown the psychological, emotional, ideological and disciplinary effects of the 'terror of prevention' (Hillyard 1993: 262) within Muslims communities. Adopting a networked approach counters impoverished state-centric accounts (Greer 2010, 2014) which fail to address how state counter-terrorism practices affect micro-contexts of Muslim communities and households (Author, forthcoming) from both real and imagined fears and are retransmitted by the subjugated group (Foucault 1977: 27). Co-opting Muslims to counter extremism means community members become accomplices of state terror tactics (Sofsky, 1997: 130-144), reproducing conditions under which they are made suspect by policing Muslim identities and practices, stigmatising members who have been subjected to counter-terrorism policing, informing on fellow Muslims to avoid 
becoming suspect themselves, or monitoring Muslims' activities under Prevent which, by engendering mistrust, is counter-productive for countering extremism or terrorism. The internal suspect body challenges neat categories of victim/oppressor emerging from intersecting (suspected) extremist/informer subjectivities. The body is an important site for negotiating suspect treatment requiring distinctions to be made between 'suspect community' and 'suspect body' categories to address how suspectification operates differently depending on Islamic comportment and regional variations.

State counter-terrorism measures have encouraged a culture of fear and suspicion which has closed down dialogue within Muslim communities and with the state. Findings suggest that independently funded, locally defined organisations which can bridge policy and community voices are more effective strategies because they support community empowerment and are trusted locally. Muslims should be able to determine outcomes beneficial to their communities based on local knowledge and need rather than being pressured into meeting state imposed requirements which are often counter-productive for building community resilience to countering terrorism and extremism. An important component is facilitating 'safe spaces' which are Muslim-led where difficult conversations can be had without fear of being reported. Legal requirements placed on a range of agencies under the Prevent duty means that alternative avenues need to be created where such critical engagement can happen. There needs to be a variety of spaces beyond the restrictive lens of security which address a broader spectrum of issues affecting Muslims in contemporary Britain such as (mis)perceptions, representation and engagement to support individuals' development and stake within British society. 
Further, to provide opportunities to build trust intra- and inter-communally and with policy-makers.

As Foucault (1977: 26) observes, the 'subjected body' is also the 'productive body.' Participants actively challenged subject positions of 'suspect' and 'suspector.' Saba's decision to leave the advisory group rather than be co-opted into undertaking internal surveillance provides one example of resistance. Such interventions illustrate that effects of being suspect infiltrating the fabric of Muslim communities can be reconciled.

1 Three Bradford women allegedly joined IS in 2015 taking their nine children with them.

2 Names are anonymised to protect participants' identities. Research was funded by a University of (name) Research scholarship for doctoral research. Ethical clearance was obtained from the University's Research Ethics Committee.

\section{References}

Alexander, C. 2007 'Cohesive Identities: The Distance between Meaning and Understanding' in M. Wetherell, M. Laflèche, R Berkeley (eds) Identity, Ethnic Diversity and Community Cohesion, London: SAGE Publications, 115-125. 
Amiraux, V. 2016 'Visibility, transparency and gossip: How did the religion of some (Muslims) become the public concern of others?', Critical Research on Religion 4(1): 37-56.

Bagguley, P. and Hussain, Y. 2008 Riotous Citizens: Ethnic Conflict in Multicultural Britain, Hampshire: Ashgate.

Bagguley, P. and Hussain, Y. 2012 'Securitized citizens: Islamophobia, racism and the 7/7 London Bombings', The Sociological Review 60(4): 715-734.

Bradford City Council. 2015 Report of the Strategic Director Environment and Sport to the meeting of the Corporate Overview and Scrutiny Committee 12 August 2015 [online]. Available at: file:///D:/Government_docs/Bradford/Prevent_report_Bradford_Council_2015_ USE.pdf (Accessed 25 November 2017).

Breen-Smyth, M. 2014 'Theorising the "suspect community": counterterrorism, security practices and the public imagination', Critical Studies on Terrorism 7(2): 223-240.

Burlet, S. and Reid, H. 1998 'A gendered uprising: political representation and minority ethnic communities', Ethnic and Racial Studies 21(2): 270-287.

Butler, J. 1997 Psychic Life of Power: theories in subjection, California: Stanford University Press.

Cage 2017 'Leaked government document names 'vetted' organisations in receipt of $£ 1.2$ million in PREVENT funding', 3 January [online]. Available at: https://cage.ngo/press-release/leaked-governmentdocument-names-vetted-organisations-in-receipt-of-1-2-million-inprevent-funding/ (Accessed 24 November 2017). 
Cantle, T. 2001 Community cohesion: a report of the independent review team, London: Home Office.

Cherney, A. and Murphy, K. 2016a "Being a "suspect community" in a post 9/11 world - The impact of the war on terror on Muslim communities in Australia', Australian and New Zealand Journal of Criminology 49(4): 480-496.

Cherney, A. and Murphy, K. 2016b 'What does it mean to be a moderate Muslim in the war on terror? Muslim interpretations and reactions', Critical Studies on Terrorism 9(2): 159-181.

Choudhury, T. and Fenwick, H. 2011 The Impact of Counter-Terrorism Measures on Muslim Communities. Manchester: Equality and Human Rights Commission.

\section{Communities and Local Government Undated Young Muslim Advisory Group} [online]. Available at: http://webarchive.nationalarchives.gov.uk/20120919132719/http: //www.communities.gov.uk/communities/preventingextremism/ymag/. (Accessed 14 August 2013).

Farrar, M. 2009 'Violent Urban Protest - Identities, Ethics and Islamism’ in G. Bhattacharyya (ed) Ethnicities and Values in a Changing World, Farnham: Ashgate, 103-118.

Fings, K. 2010 'The public face of the camps' in J. Caplan and N. Wachsmann (eds) Concentration Camps in Nazi Germany: The New Histories, London and New York: Routledge, 108-127.

Foucault, M. 1977 Discipline and Punish: The Birth of the Prison, London: Penguin Books.

Gilligan, C. 1982 In a Different Voice, Cambridge, M. A: Harvard University Press. 
Goffman, E. 1990 Stigma: Notes on the Management of a Spoiled Identity, New Jersey: Penguin Books.

Goldberg, D. T. 2009 'Racial comparisons, relational racisms: some thoughts on method', Ethnic and Racial Studies 32(7): 1271-1282.

Greer, S. 2008 'Human Rights and the Struggle Against Terrorism in the United Kingdom', European Human Rights Law Review 2:163-172.

Greer, S. 2010 'Anti-Terrorist Laws and the United Kingdom's "Suspect Muslim Community": A Reply to Pantazis and Pemberton', British Journal of Criminology 50(6): 1171-90.

Greer, S. 2014 'Reply to Marie Breen-Smyth, "Theorising the 'suspect community': counter-terrorism, security, practices and the public imagination', Critical Studies on Terrorism 7(3): 468-471.

Hickman, M. J., Thomas, L., Nickels, H. C., and Silvestri, S. 2012 'Social cohesion and the notion of "suspect communities": a study of the experiences and impacts of being "suspect" for Irish communities and Muslim communities in Britain', Critical Studies on Terrorism 5(1): 89-106.

Hillyard, P. 1993 Suspect Community: People's Experiences of the Prevention of Terrorism Acts in Britain, London: Pluto Press.

HM Government 2011 Prevent Strategy. Cm 8092, London: The Stationary Office.

HM Government 2015a Revised Prevent Duty Guidance for England and Wales, London: The Stationary Office.

HM Government 2015b Channel Duty Guidance: protecting vulnerable young people from being drawn into terrorism/Statutory guidance for channel panel members and partners of local panels [online].Available at: https://www.gov.uk/government/uploads/system/uploads/attachment_data/file/ 
425189/Channel_Duty_Guidance_April_2015.pdf. (Accessed 2 December 2017).

Home Office 2015 Local Delivery Best Practice Catalogue [online]. Available at: http://powerbase.info/images/8/8c/OSCT-Prevent_catalogue-March_2015OCR.pdf. (Accessed 25 November 2017).

Hunter, S. 2009 'Feminist psychosocial approaches to relationality, recognition and denial' in M. Ėzbilgin M (ed.) Equality, Diversity and Inclusion at Work, Cheltenham, UK, Northampton, USA: Edward Elgar, 179-194.

Husband, C. and Alam, Y. 2011 Social Cohesion and Counter-Terrorism: A Policy Contradiction?, Bristol: Policy Press.

Indices of Multiple Deprivation 2015 Bradford District in Focus [online]. Available at: file://D:/Government_docs/Bradford/deprivation_bradford_imd-in-focus.pdf (Accessed 25 November 2017).

Khan, K. 2009 Preventing Violent Extremism (PVE) \& Prevent: a response from the Muslim community [online]. Available at: http://www.annisa.org/downloads/PVE_and_Prevent__A_Muslim_response.pdf. (Accessed 20 August 2013).

Kundnani, A. 2009 Spooked! How not to prevent violent extremism, London: Institute of Race Relations.

Lewis, P. 2002 Islamic Britain: Religion, Politics, and Identity among British Muslims, London: I.B. Taurus.

McGhee, D. 2010 Security, citizenship and human rights: Shared values in uncertain times, Basingstoke: Palgrave Macmillan.

Moors, A. and Tarlo, E. 2007 'Introduction', Fashion Theory 11(2/3): 133-142. 
Mythen, G. 2012 "No one speaks for us": security policy, suspected communities and the problem of voice', Critical Studies on Terrorism 5(3): 409-424.

Mythen, G. and Walklate, S. 2006 'Criminology and Terrorism: Which Thesis? Risk Society or Governmentality?' British Journal of Criminology 46(3): 379-398.

Mythen, G., Walklate, S. and Khan, F. 2009 'I'm a Muslim but I'm not a terrorist:

Victimization, risky identities and the performance of safety', British Journal of Criminology 49(6): 736-754.

Nasser, N. 2003 'The Space of Displacement: Making Muslim South Asian Place in British Neighborhoods', TDSR XV(1): 7-21.

Nawaz, I. and Warrich, S. 2007 Information Guide for Muslim Communities in Dealing with Anti-Terrorism Raids/Arrests, London: Association of Muslim Lawyers.

O'Toole, T., Meer, N., DeHanas, D. N., Jones, S. H. and Modood, T. 2016 'Governing through Prevent? Regulation and Contested Practice in StateMuslim engagement', Sociology 50(1): 160-177.

Office for National Statistics 2013. Census 2011: Ethnic group, local authorities in the United Kingdom.

Pantazis, C. and Pemberton, S. 2009 'From the "Old" to the "New" Suspect Community: Examining the Impacts of Recent UK Counter-Terrorist Legislation', British Journal of Criminology 49(5): 646-666.

Pantazis, C. and Pemberton, S. 2011 'Restating the Case for the "Suspect Community": A Reply to Greer', British Journal of Criminology 51(6): 10541062. 
Poynting, S. and Mason, V. 2006 'Tolerance, freedom, justice and peace? : Britain, Australia and anti-Muslim racism since 11th September 2001', Journal of Intercultural Studies 27(4): 365-392.

Ragazzi, F. 2016 'Suspect community or suspect category? The impact of counterterrorism as "policed multiculturalism", Journal of Ethnic and Migration Studies 42(5): 724-741.

Rashid, N. 2013 'Giving the silent majority a stronger voice? Initiatives to empower Muslim women as part of the UK's "War on Terror"', Ethnic and Racial Studies 37(4): 589-604.

Saeed, T. 2016 Islamophobia and Securitization: Religion, Ethnicity and the Female Voice, Switzerland: Springer International Publishing.

Sanghera, G. and Thapar-Björkert, S. 2008 'Methodological dilemmas: gatekeepers and positionality in Bradford', Ethnic and Racial Studies 31(3): 543-562.

Sentas, V. 2014 Traces of terror: Counter terrorism law, policing and race, Oxford: Oxford University Press.

Sheridan, L. and Gillett, R. 2005 'Major World Events and Discrimination', Asian Journal of Social Psychology 8(2): 191-197.

Sofsky, W. 1997 [1993] The Order of Terror: The Concentration Camp, (W. Templer trans). Princeton: Princeton University Press.

Spalek, B. 2010 'Community policing, trust, and Muslim Communities in Relation to “New Terrorism"', Politics \& Policy 38(4): 789-815.

Spalek, B. 2011 "'New Terrorism" and Crime Prevention Initiatives Involving Muslim Young People in the UK: Research and Policy Contexts,' Religion, State \& Society 39(2-3): 191-207. 
Spalek, B. and Imtoual, A. 2007 'Muslim Communities and Counter-Terror Responses: "Hard" Approaches to Community Engagement in the UK and Australia', Journal of Muslim Minority Affairs 27(2): 185-202.

Spalek, B. and McDonald, L. Z. 2009 ‘Terror Crime Prevention: Constructing Muslim Practices and Beliefs as "Anti-Social" and "Extreme" through CONTEST 2', Social Policy and Society 9(1): 123-132.

Tarlo, E. 2010. Visibly Muslim: Fashion, Politics, Faith, Oxford: Berg.

Thomas, P. 2017 'Changing experiences of responsibilisation and contestation within Counter-Terrorism policies: The British Prevent experience', Policy and Politics 45(3): 305-321.

Tyrer, D. 2008 'The unbearable whiteness of seeing: moderated Muslims, (in)/visibilities and Islamophobia', Thinking Thru' Islamophobia/A Symposium [online]. Available at: http://www.sociology.leeds.ac.uk/assets/files/research/cers/Islamophobia\%20 Symposium\%20Papers\%20e-working\%20paper\%20(3).pdf, 48-53. (Accessed 26 July 2017).

Zempi, I. and Chakraborti, N. 2014 Islamophobia, Victimisation and the Veil, Basingstoke: Palgrave Macmillan. 